\title{
Perilaku Berisiko HIV/AIDS Pada Remaja Sma Di Wilayah Kerja UPTD Puskesmas Harapan Raya Pekanbaru Tahun 2018
}

\author{
Guspratiwi S.Abdi' ${ }^{1}$ Toha Muhaimin'2 ${ }^{2}$ Lita $^{3}$, Nurlisis ${ }^{4}$, Syamsul Bahri Riva'i ${ }^{5}$ \\ Muhammad Muzakir Fahmi6
}

\author{
1,6Mahasiswi Program Studi Magister Kesehatan Masyarakat STIKes Hang Tuah \\ 2Universitas Indonesia \\ 3,4,5 STIKes Hang Tuah Pekanbaru \\ Email : guspratiwisa@gmail.com
}

\begin{abstract}
The UPTD Puskesmas the hope of Raya Pekanbaru owns the number of be in the low teens the age of 15-24 the years that came and visited and hiv testing as much as 292 people, have been given counseling as much as 200 people, told there were hiv positive 2 a person, and given chief assessor numbers counseling after the test hiv as much as 207 people. Data on the sexually transmitted infection (IMS) in adolescents the age of 15-24 years who got serious disease would as much as 92 a person with 4 the syphilis and 15 a person gonorrhea (GO).The purpose of this research to gain an understanding of the factors causing the behavior runs the risk of HIV/AIDS in adolescents. The place of research in four to senior high school in the working areas of the UPTD Puskesmas the hope of Raya Pekanbaru. A design study analytic cross-sectional with the total sample 314 teenagers appeared.An analyzer used the univariat, bivariat (chi square), and multivariate (regression double logistic). The analysis multivariate variable are associated with risky behavior hiv the sexes (OR: 28,838 CI: 95 \% 9,08491,549) and neighborhood (OR: 0,104 CI: 95 \% 0,026-0,418). Conclusions sexes 28 times had a chance to behave risky HIV/AIDS and neighborhood 3 times risky HIV/AIDS. Advice recommended for the UPTD Puskesmas and schools turn back pkpr and activities youth to enhancing teen health.
\end{abstract}

Keywords : :HIV-AIDS, Behavior, Puskesmas, Youth, Risk.

\begin{abstract}
Abstrak
UPTD Puskesmas Harapan Raya Pekanbaru memilki jumlah remaja usia 15-24 tahun tahun yang berkunjung dan tes HIV sebesar 292 orang, diberi konseling sebesar 200 orang, positif HIV 2 orang, dan diberi konseling setelah tes HIV sebesar 207 orang. Sedangkan data Infeksi Menular Seksual (IMS) pada remaja usia 15-24 tahun yang berkunjung sebesar 92 orang dengan 4 orang sifilis dan 15 orang gonore (GO). Tujuan penelitian ini untuk mengetahui faktor penyebab perilaku berisiko HIV/AIDS pada remaja. Tempat penelitian di empat SMA di wilayah kerja UPTD Puskesmas Harapan Raya Pekanbaru. Metode penelitian analytic cross-sectional dengan jumlah sampel 314 orang remaja. Analisa yang digunakan yaitu univariat, bivariat (chi square), dan multivariat (regresi logistic ganda). Hasil analisis multivariat variabel yang berhubungan dengan perilaku berisiko HIV AIDS yaitu jenis kelamin (OR: 28,838 CI: 95\% 9,084-91,549) dan lingkungan tempat tinggal (OR: 0,104 CI: 95\% 0,026-0,418. Kesimpulan jenis kelamin berisiko 28 kali untuk berperilaku berisiko HIV-AIDS dan lingkungan tempat tinggal berbanding terbalik 3 kali berisiko HIV/AIDS. Saran direkomendasikan untuk UPTD Puskesmas dan sekolah mengaktifkan kembali PKPR dan kegiatan remaja untuk meningkatkan kesehatan remaja.
\end{abstract}




\section{PENDAHULUAN}

Data HIV-AIDS di kota Pekanbaru mengalami peningkatan setiap tahunnya. Pada tahun 2014 terjadi 412 kasus HIV dan AIDS 171 kasus, tahun 2015 menjadi 550 kasus dan AIDS 253 kasus, selanjutnya mengalami peningkatan lagi pada tahun 2016 menjadi 586 kasus dan AIDS menjadi 280 kasus, dan tahun 2017 menjadi 798 kasus HIV dan 473 kasus AIDS. Hal ini perlunya peningkatan pengetahuan tentang kesehatan reproduksi kepada remaja agar terhindar dari HIVAIDS. Adapun menurut Peraturan Pemerintah (PP) Nomor 61 tahun 2014 tentang Kesehatan Reproduksi, Kesehatan Reproduksi adalah keadaan sehat secara fisik, mental, dan sosial secara utuh, tidak semata-mata bebas dari penyakit atau kecacatan yang berkaitan dengan sistem, fungsi, dan proses reproduksi. Dalam PP No. 61 tahun 2014 juga diatur peran pemerintah dalam menjamin terwujudnya Kesehatan Reproduksi salah satunya adalah Pusat Kesehatan Masyarakat (Puskesmas) (Kementerian Kesehatan Republik Indonesia, 2014)

Diwilayah kerja UPTD Puskesmas Harapan Raya Pekanbaru jumlah remaja usia 15-24 tahun tahun yang berkunjung dan tes HIV sebesar 292 orang, diberi konseling sebesar 200 orang, positif HIV 2 orang, dan diberi konseling setelah tes HIV sebesar 207 orang. Sedangkan data Infeksi Menular Seksual (IMS) pada remaja usia 15-24 tahun yang berkunjung sebesar 92 orang dengan 4 orang sifilis dan 15 orang gonore (GO) (UPTD Puskesmas Harapan Raya Pekanbaru, 2018).

Hasil survei penduduk antar sensus 2015 menunjukkan bahwa penduduk usia 15-24 tahun mencapai 42.061,2 juta atau sebesar 16,5 persen dari total penduduk Indonesia. Hasil royeksi penduduk menunjukkan bahwa jumlah penduduk usia remaja ini akan mengalami peningkatan hingga tahun 2030 dan kemudian menurun sesudahnya. Perubahan jumlah penduduk usia remaja tersebut terkait dengan transisi demografi di Indonesia, dimana angka fertilitas yang menurun telah mengubah struktur usia penduduk. Awalnya, proporsinya terbesar adalah penduduk muda (usia 0-14 tahun). Namun seiring dengan menurunnya fertilitas, terjadi perubahan dimana proporsi penduduk yang dominan bukan lagi penduduk muda tetapi penduduk usia produktif (1564 tahun). Di antara mereka yang ada dalam kelompok usia produktif tersebut adalah remaja usia 15-24 tahun (Kusumaryani \& Antarwati, 2017).

Terjadinya peningkatan jumlah remaja di Provinsi Riau dari tahun 2010 sampai 2017. Sedangkan populasi remaja di kota Perkanbaru usia 10-14 tahun laki-laki sebesar 43.553 orang dan perempuan 40.616 orang dengan jumlah 84.169 orang. Usia 15-19 tahun laki-laki sebesar 48.825 orang dan perempuan sebesar 50.616 orang dengan jumlah sebesar 99.341 orang (Badan Pusat Statistik Indonesia, 2014). Populasi remaja di kawasan UPTD Puskesmas Harapan Raya usia 10-14 tahun laki-laki sebesar 4.698 orang dan perempuan sebesar 4.419 orang dengan jumlah 9.117 orang. Remaja usia 15-19 tahun laki-laki sebesar 5.728 orang dan perempuan sebesar 5.651 orang dengan jumlah 11.379 orang. Jadi ada remaja usia 10-19 tahun sebesar 20.556 orang di wilayah kerja UPTD Puskesmas Harapan Raya Pekanbaru (Profil UPTD Puskesmas Harapan Raya Pekanbaru tahun 2017, 2017). 
Dari hasil penelitian Fahmi (2018) bahwa sudah 4 tahun terakhir sudah tidak aktif program kesehatan remaja seperti program Pelayanan Kesehatan Peduli Remaja (PKPR) yang tergabung dalam satu penanggung jawab dengan program pelayanan HIV/AIDS di UPTD Puskesmas Harapan Raya Pekanbaru. Hal ini juga di perkuat dari hasil wawancara kepada Penanggung Jawab program PKPR dan HIV/AIDS bahwa pelayanan kesehatan remaja di UPTD Puskesmas Harapan Raya Pekanbaru hanya melakukan penyuluhan saja.

Berbagai permasalahan tersebut peneliti tertarik untuk melakukan penelitian tentang "perilaku berisiko HIV-AIDS pada remaja SMA di wilayah kerja UPTD Puskemas Harapan Raya Pekanbaru tahun 2018"

\section{METODE}

Jenis penelitian yang digunakan adalah kuantitatif analitik observasional dengan jenis desain studi penampang analitik (analytic cross-sectional). Lokasi penelitian dilakukan di 4 Sekolah Menengah Atas (SMA) wilayah kerja UPTD Puskesmas Harapan Raya Pekanbaru. Subjek penelitian ini adalah remaja yang terdaftar disekolah dengan jumlah sampel 314. Teknik pengambilan sampel dengan menggunakan kriteria inklusi dan eklusi. Analisis data dilakukan secara multivariat dengan metode regresi linier sederhana.

\section{HASIL}

Variabel yang berhubungan signifikan : dari hasil multivariat didapatkan OR dari variabel jenis kelamin 28,838 artinya variable jenis kelamin lebih berisiko berat melakukan perilaku berisiko HIV-AIDS sebanyak 28,838 kali dan OR variabel lingkungan tempat tinggal 0,104 artinya variabel lingkungan tempat tinggal berisiko 0,104 kali.

Variabel yang dominan : Variabel jenis kelamin dominan berhubungan dengan perilaku berisiko HIV-AIDS pada remaja di UPTD Puskesmas Harapan Raya. Variabel Confounding : Variabel sikap, pngetahuan dan akses media informasi. Variabel yang tidak berhubungan signifikan : Variabel sikap, pengetahuan dan akses media informasi tidak memiliki hubungan sebab akibat dengan perilaku berisiko HIV-AIDS pada remaja di UPTD Puskesmas Harapan Raya Pekanbaru.

\section{PEMBAHASAN}

1. Variabel yang berhubungan secara signifikan dengan Perilaku Berisiko HIV-AIDS di wilayah kerja UPTD Puskesmas Harapan Raya Pekanbaru

\section{a. Jenis Kelamin}

Dari hasil penelitian yang dilakukan, di dapat bahwa terdapat hubungan yang signifikan antara jenis kelamin dengan perilaku berisiko HIV/AIDS pada remaja, dengan p-value 0,000 (POR;28,838); CI 95\% : 9,084-91,549. Hal ini berarti remaja yang memiliki jenis kelamin laki-laki lebih berisiko 28 kali dari pada remaja yang berjenis kelamin perempuan.

Hal ini sejalan dengan beberapa penelitian bahwa adanya hubungan yang bermakna dengan perilaku berisiko kesehatan remaja di mana laki-laki ternyata lebih berisiko dalam berperilaku kesehatan dari pada perempuan ( $\mathrm{OR}=5,363,95 \% \mathrm{CI}=2,890-9,954$ ) (Hidayangsih, Tjandrarini, Mubasyiroh, \& Supanni, 2009). 
Penelitian Nuzzillah (2015) juga menyebutkan bahwa laki laki mempunyai peluang untuk berperilaku seksual berisiko 4,41 kali dibandingkan dengan perempuan $(95 \% \mathrm{CI}=2,48$ 841). Lestary and Sugiharti (2011) faktor yang paling dominan berhubungan dengan perilaku berisiko pada perilaku HIV-AIDS adalah jenis kelamin. Jenis kelamin yang paling dominan adalah laki-laki. Remaja laki-laki berpeluang 5 kali lebih besar untuk hubungan seksual pranikah. Hidayangsih et al. (2009) juga menyebutkan jenis kelamin sangat berpengaruh terhadap penyakit kesehatan reproduksi terutama berjenis kelamin laki-laki berisiko 4,41 kali dibandingkan dengan jenis kelamin perempuan.

Hasil penelitian tersebut menunjukkan bahwa terdapat hubungan antara jenis kelamin dengan perilaku berisiko HIV/AIDS. Remaja yang berjenis kelamin laki-laki tingkat pengetahuannya tentang informasi HIV/AIDS lebih banyak dibandingkan perempuan.hal ini disebabkan kemungkinan karena remaja yang berjenis kelamin laki-laki lebih banyak berada di luar rumah sehingga mudah mendapatkan segala sumber informasi. Selain itu remaja berjenis kelamin laki-laki kemungkinan memiliki teman dan pergaulan yang sangat luas antara teman sebayanya sehingga bisa saja remaja laki-laki dengan mudah terjerumus kedalam perilaku dan pengaruh yang buruk.

Hasil penelitian (Ernawati, 2018) menyatakan bahwa Teman sebaya merupakan factor dominan yang berhubungan dengan perilaku seksual remaja dengan nilai $(\mathrm{OR}=4,111)$ artinya pengaruh buruk teman sebaya berpeluang 4 kali dibandingkan pengaruh baik teman sebaya terhadap perilaku seksual.

\section{b. Lingkungan Tempat Tinggal}

Hasil penelitian yang dilakukan, di dapat bahwa terdapat hubungan yang signifikan antara lingkungan tempat tinggal dengan perilaku berisiko HIV/AIDS pada remaja, dengan p-value 0,001 (POR; 0,104); CI 95\% : 0,026-0,418. Hal ini berarti remaja yang tinggal dilingkungan tempat tinggal positif 0,104 kali lebih berisiko dari pada remaja yang tinggal di lingkungan tempat tinggal negatif.

Penelitian ini berbanding terbalik dengan penelitian Oktarina, Hanafi and Budisuari (2009) Faktor wilayah sangat berpengaruh terhadap perilaku berisiko HIV-AIDS. Masyarakat diwilayah perkotaan cenderung berpengetahuan baik tentang HIV/AIDS baik 0,4 kali dibandingkan desa. Hal ini menunjukan tempat atau wilayah sangat penting untuk tahu terhadap perilaku berisiko HIV-AIDS. Didapatkan hasil penelitian Sudikno, Simanungkalit and Siswanto (2010) pengethuan lebih baik pada remaja yang tinggal di Perkotaan tetapi paling berisiko terhadap perilaku HIV-AIDS pada wilayah perkotaan.

Akses tempat fasilitas kesehatan juga sangat berpengaruh terhadap perilaku berisiko HIVAIDS menurut penelitian Nurachmah and Mutikasari (2009). Sesuai dengan Sari and Ismail (2012) bahwa lingkungan lingkungan tempat tinggal mempengaruhi pengetahuan remaja tentang HIV-AIDS remaja. Fakto pemungkin seperti ketersediaan tempat berisiko sangat berpengaruh terhadap perilaku berisiko HIV-AIDS. Ketersediaan fasilitas-fasilitas yang berisiko seperti hotel, tempat karoke, dan tempat hiburan lainnya seperti juga adanya 
warung jablay sebagai tempat transaksi awal, dan warung jablay sebagai tempat istirahat dan nongkrong para supir atau pekerja lain.

Beberapa penelitian didapatkan bahwa remaja yang tinggal di lingkungan tempat tinggal negatif akan berisiko berperilaku HIV-AIDS dan hasil penelitian di lapangan di temukan bahwa remaja yang tinggal di lingkungan positif lebih berisiko HIV/AIDS dibandingkan remaja yang tinggal di lingkungan negatif, hal ini berbanding terbalik dengan penelitian yang sudah ada.

Remaja yang tinggal di lingkungan tempat tinggal positif belum tentu berperilaku baik terhadap perilaku berisiko HIV/AIDS. Kebanyakan perilaku remaja sangat bertentangan dengan nilai-nilai yang baik, remaja tidak suka dikekang dan banyak aturan. Apabila di lingkungan tepat tinggal banyak aturan dan selalu dikekang maka remaja ini akan memberontak dan bisa saja menimbulkan perilaku berisiko khususnya tentang HIV/AIDS. Bisa saja remaja yang tinggal di lingkungan baik akan terlihat dan berperilaku baik saat berada di rumah atau dihadapan orang tua, dan saat berada di luar sebaliknya, untuk itu jadikan lah remaja sahabat, dan remaja ingin didengarkan,

2. Variabel yang tidak berhubungan secara signifikan dengan Perilaku Berisiko HIV-AIDS di wilayah kerja UPTD Puskesmas Harapan Raya Pekanbaru

a. Sikap

Dari hasil penelitian yang dilakukan didapatkan bahwa variabel sikap tidak berhubungan dengan perilaku berisiko HIV/AIDS dengan p-value 0,075 >0,05. Hasil penelitian ini sejalan dengan hasil penelitian yang dilakukan (Nuzzilah, 2015) yang menyatakan bahwa tidak ada hubungan antara sikap dengan pencegahan HIV/AiDS dengan $\mathrm{p}$-value $=0,256 ; \mathrm{RP}=1,6 ; \mathrm{CI}=$ 0,8-3,37).

Sikap terdiri dari berbagai tingkatan yaitu: menerima (receiving) diartikan bahwa orang (subjek) mau dan memperhatikan stimulus yang diberikan (objek). Merespon (responding) yaitu memberikan jawaban apabila ditanya. Menghargai (valuing) yaitu mengajak orang lain untuk mengerjakan atau mendiskusilkan suatu masalah. Bertanggung jawab (responsible) yaitu siap dengan segala risiko terhadap sesuatu yang telah dipilihnya (Notoatmodjo, 2012). Dari hasil penelitian di lapangan diperoleh remaja yang bersikap positif justru lebih banyak berisiko HIV/AIDS sehingga didapatkan hubungan yang tidak signifikan untuk variabel ini.

Berdasarkan hasil penelitian ini didapatkan bahwa responden yang memiliki sikap positif lebih banyak dibandingkan responden yang memiliki sikap negatif. Hal ini dapat dipengaruhi oleh faktor pengetahuan dan lingkungan responden sehingga dapat memotivasi siswa untuk menetukan sikap positif atau negatif berdasarkan pengalaman yang diamati dan pengaruh lingkungan (Yulianingsih, 2015).

\section{b. Pengetahuan}

Dari Hasil penelitian yang dilakukan didapatkan bahwa variabel pengetahuan tidak berhubungan dengan perilaku berisiko HIV/AIDS dengan p-value 0,803>0,05 seajalan dengan hasil penelitian (Chibtia, 2014) tidak ada hubungan pengetahuan dengan perilaku 
pencegahan HIV/AIDS pada remaja komunitas anak jalanan dengan p-value 0,174 artinya p > 0,05. Berdasarkan hasil penelitian (Afritayeni, 2018) tidak ada hubungan pengetahuan dengan perilaku seksual berisiko pada remaja terinfeksi HIV/AIDS dimana dari hasil uji statistik didapatkan $\mathrm{p}$ value 1,00 yang artinya $\mathrm{p}$. 0,05 tidak ada hubungan yang signifikan antara pengetahuan dengan perilaku seksual berisiko pada remaja.

Penelitian di atas tidak sejalan dengan beberapa penelitian yang dilakukan oleh Yulianingsih (2015) diperoleh nilai $\mathrm{p}=0,000<\alpha 0,05$ maka dapat disimpulkan terdapat hubungan yang sangat bermakna antara pengetahuan dengan tindakan berisiko tertular HIV/AIDS pada siswa SMA negeri dikota gorontalo dgn nilai OR yang menunjukkan bahwa siswa yang berpeluang 3,6 kali lebih besar melakukan tindakan berisiko dibandingkan dengan siswa yang berpengetahuan baik. Tetapi dari penelitian Situmeang, Syarif and Mahkota (2017) mennyebutkan remaja mempunyai pengetahuan yang kurang tentang HIV-AIDS. Pengetahuan yang kurang tentang HIV-AIDS berhubungan dnegan stigma terhadap ODHA.

Hasil uji statistik menunjukan bahwa persepsi tentang pengetahuan, sikap dan pencegahan berhubungan dengan upaya pencegahan HIV/AIDS melalui perilaku berisiko tertular pada siswa SLTP $(p=0,000)$ hasil menunjukkan bahwa upaya pencegahan HIV/AIDS melalui perilaku berisiko tertular memerlukan peningkatan pemahaman tentang pengetahuan, sikap dan upaya pencegahan secara terus menerus dan sebaliknya para siswa siap dan sadar untuk mempelajarinya (Ratnaningsih, 2015)

Menurut Sarwono, manfaat pengetahuan mengenai seksualitas adalah: a) mengerti tentang perbedaan kesehatan reproduksi antara pria dan wanita dalam keluarga, pekerjaan dan seluruh kehidupan yang selalu berubah dan berbeda dalam tiap masyarakat dan kebudayaan, b) mengerti tentang peranan kesehatan reproduksi dalam kehidupan manusia, dan keluarga, c) mengembangkan pengertian tentang diri sendiri sehubungan dengan fungsi dan kebutuhan seks, d) membantu untuk mengembangkan kepribadian sehingga remaja mampu untuk mengambil keputusan yang bertanggung jawab.

Kesimpulan dalam penelitian ini hasil penelitian tidak sesuai dengan teori dan bebrapa hasil yang sudah ada sebelumnya bahwa adanya hubungan pengetahuan dengan perilaku berisiko HIV/AIDS pada remaja. Dilihat dari hail univariat pada penelitian ini remaja yang berpengetahuan baik lebih tinggi dari remaja yang berpengertahuan kurang yaitu 181 $(57,6)$, maka peneliti berasumsi pengetahuan yang baik belum tentu seseorang itu dapat berperilaku baik pula karena pengetahun dan perilaku dua hal yang berbeda. Bisa saja pengetahuan remaja tentang HIV/AIDS itu baik tapi belum tentu tindakannya sesuai dengan pengetahuannya.

\section{c. Akses Media Informasi}

Dari Hasil penelitian yang dilakukan didapatkan bahwa variabel akses media informasi tidak berhubungan dengan perilaku berisiko HIV/AIDS dengan p-value 0,240 >0,05. Sejalan dengan hasil penelitian (Ernawati,2018) didapatkan $\mathrm{p}$ value 0,356 artinya Tidak ada 
hubungan yang signifikan antara keterpaparan sumber informasi yang diperoleh remaja terhadap perilaku seksual berisiko.

Sekarini (2011) menyatakan sifat media informasi mengandung nilai manfaat, tetapi selain itu tidak sengaja menjadi media yang mampu menyebarkan nilai-nilai yang baru muncul dimasyarakat. Sejalan dengan hasil penelitian dari Mandey (2014) bahwa yang sangat berpengaruh terhadap perilaku seksual pranikah berisiko pada mahasiswa yaitu akses media informasi (pornografi). Penelitian ini juga di perkuat dengan penelitian Mariani and Arsy (2017) bahwa media informasi sangat berpengaruh terhadap perilaku seksual pada remaja. Semakin besar pengetahuan tentang kesehatan reproduksi maka tidak ada dan terhindar dari akses infromasi seksual yang tidak baik. Novitamala et al. (2016) munculnya aplikasi-aplikasi pendukung dan majalah dewasa menjadi faktor berisiko perilaku penularan HIV-AIDS. Peran media masa dan internet dalam memberikan informasi merupakan hal yang sangat penting dalam upaya peningkatan pengetahuan remaja dalam hal pemberian infromasi yang baik tentang HIV-AIDS (Yulianingsih, 2015).

Sumber informasi remaja dalam upaya pencegahan HIV-AIDS sudah sangat banyak dimana 93,4\% siswa remaja sudah sangat baik mendapatkan informasi melalui teknologi yang semakin maju dan canggih (Haringi, Yuniar, \& Jufri, 2016). Musthofa dalam Mandey (2014) Media sangat berperan dalam mentransformasikan perubahan nilai seksualitas yaitu dari situs-situs internet yang dengan mudah diakses sehingga banyak remaja yang mulai mencari tahu bahkan mempraktikkan hal-hal yang belum pantas dilakukan bersama pasangannya.

Infromasi dan akses media yang mudah didapat membuat remaja mudah memperoleh halhal yang berbau pornografi dan majalah, televisi, dan internet sedangkan remaja cenderung meniru atau mencoba hal baru demi menjawab penasaran remaja (Mariani \& Arsy, 2017). Akses informasi melalui media informasi menjadi sangat penting terhadap pengetahuan remaja tentang HIV-AIDS (Sari \& Ismail, 2012)

Peneliti berasumsi berdasarkan hasil penelitian ini dan beberapa perbandingan penelitian diatas dapat disimpulkan bahwa akses media informasi tidak selalu berpengaruh buruk apabila seseorang dapat menggunakannya dengan benar.

\section{Faktor Dominan yang Berhubungan dengan Perilaku Berisiko HIV-AIDS pada Remaja di} wilayah kerja UPTD Puskesmas Harapan Raya Pekanbaru

Hasil analisis multivariat ternyata faktor dominan paling tinggi pertama adalah jenis kelamin dengan nilai (OR 28,838) berhubungan dengan perilaku berisiko HIV-AIDS pada remaja di wilayah kerja UPTD Puskesmas Harapan Raya Pekanbaru, artinya berjenis kelamin laki-laki berpeluang 28 kali dibandingkan dengan remaja berjenis kelamin perempuan. Hal ini sejalan dengan beberapa penelitian bahwa adanya hubungan yang bermakna dengan perilaku berisiko kesehatan remaja di mana laki-laki ternyata lebih berisiko dalam berperilaku kesehatan dari pada perempuan $(\mathrm{OR}=5,363,95 \% \mathrm{CI}=2,890-9,954)$ (Hidayangsih et al., 2009). Penelitian 
Nuzzillah (2015) juga menyebutkan bahwa laki laki mempunyai peluang untuk berperilaku seksual berisiko 4,41 kali dibandingkan dengan perempuan (95\% CI = 2,48-841).

\section{Faktor confounding}

Faktor confounding atau yang dapat mempengaruhi pengamatan hubungan secara keseluruhan yaitu pada: sikap ( $p$ value $=0,078$ ), pengetahuan ( $p$ value $=0,803$ ) dan akses informasi media informasi ( $\mathrm{p}$ value $=0,240$ ) yang dalam analisis bivariat masih mempunyai hubungan yang signifikan pada perilaku berisiko HIV-AIDS pada remaja di UPTD Puskesmas Harapan

$$
\text { Raya }
$$

Pekanbaru.

Tabel 1. Hasil Univariat

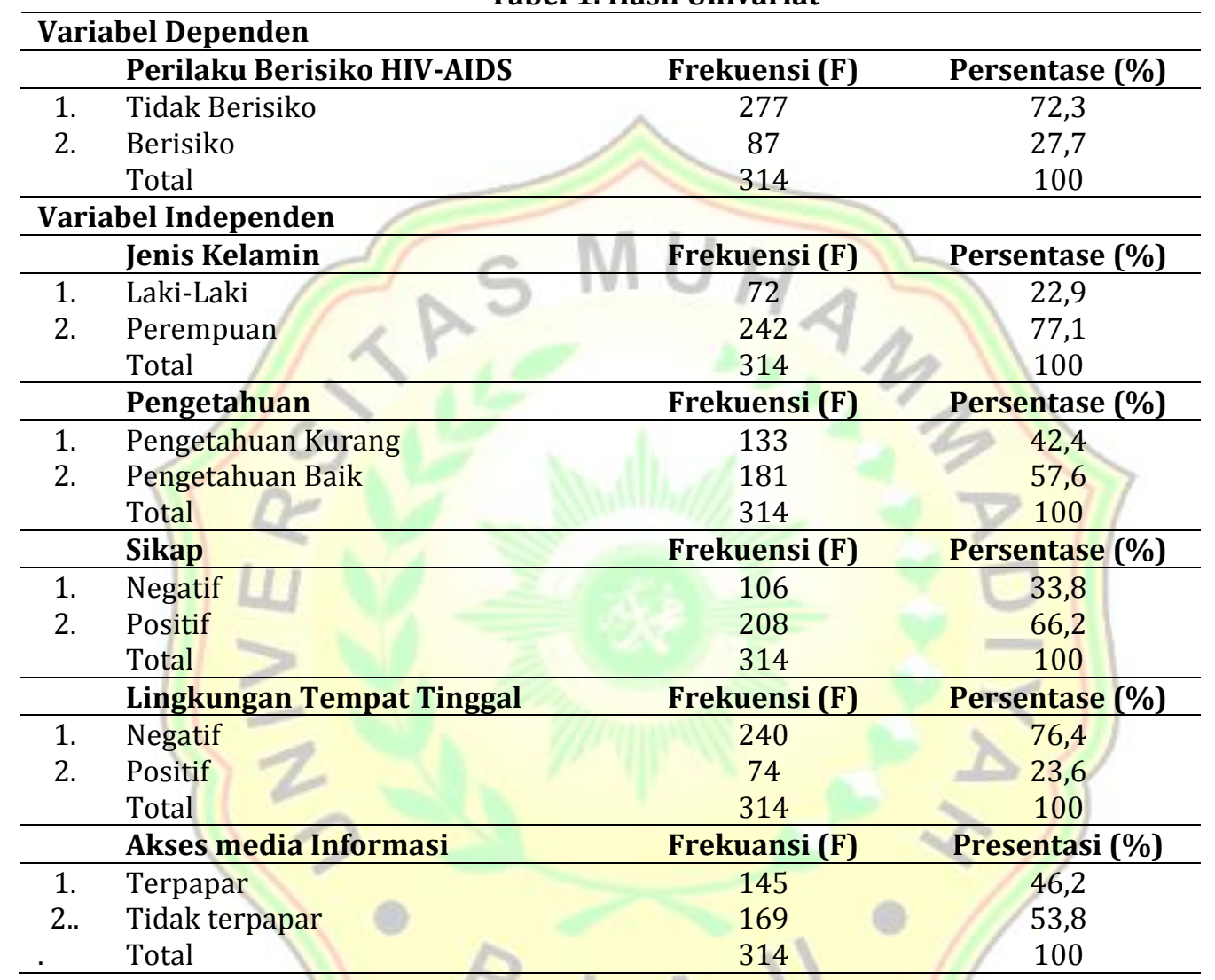

Tabel 2. Hasil Bivariat

\begin{tabular}{|c|c|c|c|c|c|c|c|c|}
\hline \multirow{3}{*}{ Variabel } & \multicolumn{4}{|c|}{$\begin{array}{c}\text { Perilaku Berisiko HIV- } \\
\text { AIDS }\end{array}$} & & & \multirow{3}{*}{$\begin{array}{c}P \text { - } \\
\text { Value }\end{array}$} & \multirow{3}{*}{ OR } \\
\hline & \multicolumn{2}{|c|}{ Berisiko } & \multicolumn{2}{|c|}{$\begin{array}{c}\text { Tidak } \\
\text { Berisiko }\end{array}$} & \multicolumn{2}{|c|}{ Jumlah } & & \\
\hline & $\mathbf{N}$ & $\%$ & $\mathbf{N}$ & $\%$ & $\mathbf{N}$ & $\%$ & & \\
\hline Jenis Kelamin & & & & & & & \multirow{4}{*}{0,000} & \multirow{4}{*}{$\begin{array}{c}115,762 \\
44,858-298,737\end{array}$} \\
\hline Laki-laki & 66 & $\begin{array}{c}91, \\
7\end{array}$ & 6 & $\begin{array}{l}8,3 \\
01\end{array}$ & 72 & 100 & & \\
\hline Perempuan & 21 & 8,7 & 221 & $\begin{array}{c}91, \\
3 \\
\end{array}$ & 242 & 100 & & \\
\hline Total & 87 & $\begin{array}{c}27 \\
7\end{array}$ & 227 & $\begin{array}{c}72, \\
3 \\
\end{array}$ & 314 & 100 & & \\
\hline \multicolumn{7}{|l|}{ Pengetahuan } & \multirow{3}{*}{0,000} & \multirow{3}{*}{$\begin{array}{c}3,066 \\
1,837-5,115\end{array}$} \\
\hline $\begin{array}{l}\text { Pengetahuan } \\
\text { kurang }\end{array}$ & 54 & $\begin{array}{c}40 \\
6 \\
\end{array}$ & 79 & $\begin{array}{c}59 \\
4 \\
\end{array}$ & 133 & 100 & & \\
\hline Pengetahuan baik & 33 & $\begin{array}{c}18, \\
2\end{array}$ & 148 & $\begin{array}{c}81, \\
8\end{array}$ & 181 & 100 & & \\
\hline
\end{tabular}




\begin{tabular}{|c|c|c|c|c|c|c|c|c|}
\hline Total & 87 & $\begin{array}{c}27 \\
7\end{array}$ & 227 & $\begin{array}{c}72, \\
3\end{array}$ & 314 & 100 & & \\
\hline Sikap & & & & & & & \multirow{4}{*}{0,003} & \multirow{4}{*}{$\begin{array}{c}2,221 \\
1,334-3,699\end{array}$} \\
\hline Negative & 41 & $\begin{array}{c}38 \\
7\end{array}$ & 65 & $\begin{array}{c}61, \\
3\end{array}$ & 106 & 100 & & \\
\hline Positif & 46 & $\begin{array}{c}22, \\
1\end{array}$ & 162 & $\begin{array}{c}77 \\
9 \\
\end{array}$ & 208 & 100 & & \\
\hline Total & 87 & $\begin{array}{c}27 \\
7\end{array}$ & 227 & $\begin{array}{c}72, \\
3\end{array}$ & 314 & 100 & & \\
\hline \multicolumn{7}{|c|}{$\begin{array}{l}\text { Ling. Tempat } \\
\text { Tinggal }\end{array}$} & \multirow{3}{*}{0,000} & \multirow{3}{*}{$\begin{array}{c}0,019 \\
0,009-0,042\end{array}$} \\
\hline Negative & 24 & $\begin{array}{c}10 \\
0\end{array}$ & 216 & 90 & 240 & 100 & & \\
\hline Positif & 63 & $\begin{array}{c}83 \\
1\end{array}$ & 11 & $\begin{array}{c}14 \\
9\end{array}$ & 74 & 100 & & \\
\hline Total & 87 & $\begin{array}{c}27 \\
7\end{array}$ & 227 & 72 , & & 100 & & \\
\hline
\end{tabular}

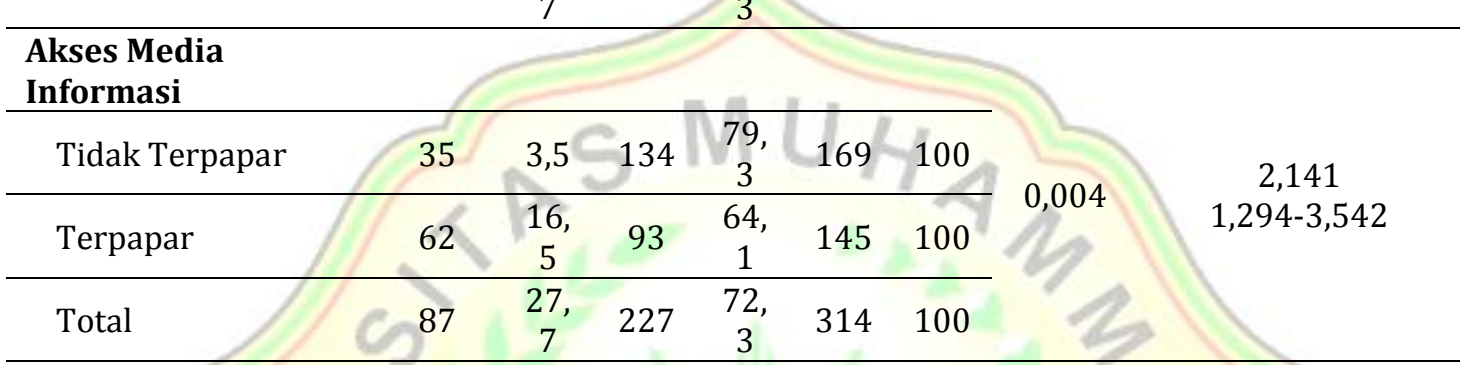

Tabel 3. Permodelan Multivariat Terakhir

\begin{tabular}{lcccc}
\hline \multirow{2}{*}{ Variabel } & \multirow{2}{*}{ P-Value } & \multirow{2}{*}{ POR } & \multicolumn{2}{c}{ 95\% Cl } \\
\cline { 4 - 5 } & & & Lower & Upper \\
\hline Jenis Kelamin & 0,000 & 28,838 & 9,084 & 91,549 \\
\hline Sikap & 0,078 & 2,186 & 0,915 & 5,222 \\
\hline Ling. Tem. Tinggal & 0,001 & 0,104 & 0,026 & 0,418 \\
\hline Pengetahuan & 0,803 & 1,023 & 0,858 & 1,219 \\
\hline Akses informasi & 0,240 & 0,531 & 0,168 & 1,526 \\
\hline
\end{tabular}

\section{KESIMPULAN}

1. Remaja yang berperilaku berisiko HIV/AIDS sebanyak 87 orang $(27,7 \%)$

2. Remaja yang berjenis kelamin laki-laki 28 kali lebih berisiko HIV/AIDS dari remaja yang berjenis kelamin perempuan.

3. Sikap tidak berhubungan dengan perilaku berisiko HIV/AIDS.

4. Remaja yang tinggal di lingkungan tempat tinggal negatif 0,104 kali berisiko HIV-AIDS dari remaja yang tinggal di lingkungan tempat tinggal positif.

5. Pengetahuan tidak berhubungan dengan perilaku berisiko HIV/AIDS.

6. Akses media informasi tidak berhubungan dengan perilaku berisiko HIV/AIDS.

7. Faktor dominan yang paling berhubungan yaitu jenis kelamin. Diketahui remaja yang berjenis kelamin laki-laki 28 kali lebih berisiko HIV AIDS dibandingkan dengan remaja berjenis kelamin perempuan. Faktor confounding yang paling berhubungan yaitu sikap dengan perilaku berisiko HIV/AIDS. 


\section{SARAN}

\section{Pihak Sekolah}

Bagi pihak sekolah pada penelitian ini ditemukan jenis kelamin dan lingkungan tempat tinggal yang berpengaruh terhaap perilaku berisiko HIV/AIDS, diharapkan menjadi bahan pertimbangan untuk memasukan kurikulum kesehatan reproduksi terutama mengenai tentang HIV-AIDS dan diberikannya siswa melalu bimbingan konseling.

\section{Pihak UPTD Puskesmas Harapan Raya Pekanbaru}

Bagi pihak UPTD Puskesmas Harapan Raya Pekanbaru sebaiknya :

a. Meningkatkan atau mengaktifkan kembali kegiatan pada Program Kesehatan Peduli Remaja (PKPR)

b. Melakukan penyuluhan secara rutin di sekolah wilayah kerja untuk meningkatkan pengetahuan remaja terhadap HIV-AIDS di wilayah

c. Membentuk kader remaja di sekolah maupun masyarakat untuk memberikan hal positif di lingkungan tempat tinggal disekitar maupun disekolah.

\section{DAFTAR PUSTAKA}

Badan Pusat Statistik Indonesia. (2014). Badan Pusat Statistik Pekanbaru.

Fahmi, M. M. (2018). Analisis program pelayanan kesehatan peduli remaja (pkpr) di UPTD Puskesmas Harapan Raya Pekanbaru. Pekanbaru.

Haringi, S., Yuniar, N., \& Jufri, N. N. (2016). Gambaran perilaku siswa SMA dalam upaya pencegahan hiv aids di wilayah kota kendari tahun 2016. Universitas Halu Oleo.

Hidayangsih, P. S., Tjandrarini, D. H., Mubasyiroh, R., \& Supanni. (2009). Faktor-faktor yang berhubungan dengan perilaku berisiko remaja di kota Makasar tahun 2009. Buletin Penelitian Kesehatan, 29(2), 88-98.

Kementerian Kesehatan Republik Indonesia. (2014). Peraturan Menteri Kesehatan Republik Indonesia Nomor 75 Tahun 2014 tentang Pusat Kesehatan Masyarakat. 2014. https://doi.org/10.1017/CB09781107415324.004

Kusumaryani, M., \& Antarwati, E. (2017). Brief Notes : Prioritaskan Kesehatan Reproduksi Remaja Untuk Menikmati Bonus Demografi. Lembaga Demografi FEB UI, 1-6. Retrieved from http://ldfebui.org/wp-content/uploads/2017/08/BN-06-2017.pdf

Lestary, H., \& Sugiharti. (2011). Perilaku berisiko remaja di Indonesia menurut survey kesehatan reproduksi remaja Indonesia (SKRRI) tahun 2007. Jurnal Kesehatan Reproduksi, 1(3), 136144. $\quad$ Retrieved from http://ejournal.litbang.depkes.go.id/index.php/kespro/article/view/1389/696

Mandey, F. K. P. (2014). Faktor-faktor yang berhubungan dengan perilaku seksual pranikah berisiko pada mahasiswa di fakultas ilmu sosial universitas negeri manado. Universitas Sam Ratulangi.

Mariani, N. N., \& Arsy, D. F. (2017). Faktor-faktor yang Mempengaruhi Perilaku Seksual Remaja di SMP Negeri 15 Kota Cirebon Tahun 2012. Jurnal Care, 5(3), 443-456.

Novitamala, N., Arifin, S., Khairiyati, L., Husaini, \& Setyaningrum, R. (2016). Analisis penyebab kasus 
penularan hiv/aids ditinjau dari faktor predisposisi, pemungkin, dan pendorong. Universitas Lambung Mangkurat Banjarbaru.

Nurachmah, E., \& Mutikasari. (2009). Faktor Pencegahan HIV / AIDS Akibat Perilaku Berisiko Tertular Pada Siswa SLTP. Makara Kesehatan, 13(2), 63-68.

Nuzzillah, N. A. (2015). Faktor-faktor yang berhubungan dengan perilaku berisiko penularan hiv/aids pada narapidana kasus narkoba di lembaga pemasyarakatan kelas I semarang tahun 2015. Universitas Negeri Semarang.

Oktarina, Hanafi, F., \& Budisuari, M. A. (2009). Hubungan Antara Karakteristik Responden, Keadaan Wilayah dengan Pengetahuan, Sikap Terhadap HIV/AIDS pada Masyarakat Indonesia. Buletin Penelitian Sistem Kesehatan, 124(4), 362-369. https://doi.org/10.22435/BPSK.V12I4.2742

Profil UPTD Puskesmas Harapan Raya Pekanbaru tahun 2017. (2017).

Ratnaningsih, D. (2015). Faktor-faktor yang berhubungan perilaku pencegahan hiv/aids pada wanita pekerja seks komersial. Universitas Sebelas Maret.

Sari, S. M., \& Ismail. (2012). Faktor-faktor yang mempengaruhi pengetahuan siswa-siswa tentang hiv/aids di smit negeri kota banda aceh. STIKes Banda Aceh. Retrieved from http://www.ejournal.uui.ac.id/jurnal/SHINTA_MAYA_SARI-23u-jurnal_shinta_maya_s.pdf

Situmeang, B., Syarif, S., \& Mahkota, R. (2017). Hubungan Pengetahuan HIV / AIDS dengan Stigma terhadap Orang dengan HIV / AIDS di Kalangan Remaja 15-19 Tahun di Indonesia ( Analisis Data SDKI Tahun 2012 ). Jurnal Epidemiologi Kesehatan Indonesia, 1(2), 35-43.

Sudikno, Simanungkalit, B., \& Siswanto. (2010). Pengetahuan hivdan aids pada remaja di indonesia (analisis data riskesdas 2010). Jurnal Kesehatan Resproduksi, 1(3), 145-154.

UPTD Puskesmas Harapan Raya Pekanbaru. (2018). DATA HIV DAN IMS REMAJA UPTD PKM HR PKU 2017.

Yulianingsih, E. (2015). Faktor-faktor yang berhubungan dengan tindakan berisiko tertular hiv/aids pada siswa SMA negeri di kota Gorontalo. JIMU, 5(2a), 311-321.

Badan Pusat Statistik Indonesia. (2014). Badan Pusat Statistik Pekanbaru.

Fahmi, M. M. (2018). Analisis program pelayanan kesehatan peduli remaja (pkpr) di UPTD Puskesmas Harapan Raya Pekanbaru. Pekanbaru.

Haringi, S., Yuniar, N., \& Jufri, N. N. (2016). Gambaran perilaku siswa SMA dalam upaya pencegahan hiv aids di wilayah kota kendari tahun 2016. Universitas Halu Oleo.

Hidayangsih, P. S., Tjandrarini, D. H., Mubasyiroh, R., \& Supanni. (2009). Faktor-faktor yang berhubungan dengan perilaku berisiko remaja di kota Makasar tahun 2009. Buletin Penelitian Kesehatan, 29(2), 88-98.

Kementerian Kesehatan Republik Indonesia. (2014). Peraturan Menteri Kesehatan Republik Indonesia Nomor 75 Tahun 2014 tentang Pusat Kesehatan Masyarakat. 2014. https://doi.org/10.1017/CB09781107415324.004

Kusumaryani, M., \& Antarwati, E. (2017). Brief Notes : Prioritaskan Kesehatan Reproduksi Remaja Untuk Menikmati Bonus Demografi. Lembaga Demografi FEB UI, 1-6. Retrieved from http://ldfebui.org/wp-content/uploads/2017/08/BN-06-2017.pdf 
Lestary, H., \& Sugiharti. (2011). Perilaku berisiko remaja di Indonesia menurut survey kesehatan reproduksi remaja Indonesia (SKRRI) tahun 2007. Jurnal Kesehatan Reproduksi, 1(3), 136144.

Retrieved

from

http://ejournal.litbang.depkes.go.id/index.php/kespro/article/view/1389/696

Mandey, F. K. P. (2014). Faktor-faktor yang berhubungan dengan perilaku seksual pranikah berisiko pada mahasiswa di fakultas ilmu sosial universitas negeri manado. Universitas Sam Ratulangi.

Mariani, N. N., \& Arsy, D. F. (2017). Faktor-faktor yang Mempengaruhi Perilaku Seksual Remaja di SMP Negeri 15 Kota Cirebon Tahun 2012. Jurnal Care, 5(3), 443-456.

Novitamala, N., Arifin, S., Khairiyati, L., Husaini, \& Setyaningrum, R. (2016). Analisis penyebab kasus penularan hiv/aids ditinjau dari faktor predisposisi, pemungkin, dan pendorong. Universitas Lambung Mangkurat Banjarbaru.

Nurachmah, E., \& Mutikasari. (2009). Faktor Pencegahan HIV / AIDS Akibat Perilaku Berisiko Tertular Pada Siswa SLTP. Makara Kesehatan, 13(2), 63-68.

Nuzzillah, N. A. (2015). Faktor-faktor yang berhubungan dengan perilaku berisiko penularan hiv/aids pada narapidana kasus narkoba di lembaga pemasyarakatan kelas I semarang tahun 2015. Universitas Negeri Semarang.

Oktarina, Hanafi, F., \& Budisuari, M. A. (2009). Hubungan Antara Karakteristik Responden, Keadaan Wilayah dengan Pengetahuan, Sikap Terhadap HIV/AIDS pada Masyarakat Indonesia. Buletin Penelitian Sistem Kesehatan, 124(4), 362-369. https://doi.org/10.22435/BPSK.V12I4.2742

Profil UPTD Puskesmas Harapan Raya Pekanbaru tahun 2017. (2017).

Ratnaningsih, D. (2015). Faktor-faktor yang berhubungan perilaku pencegahan hiv/aids pada wanita pekerja seks komersial. Universitas Sebelas Maret.

Sari, S. M., \& Ismail. (2012). Faktor-faktor yang mempengaruhi pengetahuan siswa-siswa tentang hiv/aids di smit negeri kota banda aceh. STIKes Banda Aceh. Retrieved from http://www.ejournal.uui.ac.id/jurnal/SHINTA_MAYA_SARI-23u-jurnal_shinta_maya_s.pdf

Situmeang, B., Syarif, S., \& Mahkota, R. (2017). Hubungan Pengetahuan HIV / AIDS dengan Stigma terhadap Orang dengan HIV / AIDS di Kalangan Remaja 15-19 Tahun di Indonesia ( Analisis Data SDKI Tahun 2012 ). Jurnal Epidemiologi Kesehatan Indonesia, 1(2), 35-43.

Sudikno, Simanungkalit, B., \& Siswanto. (2010). Pengetahuan hivdan aids pada remaja di indonesia (analisis data riskesdas 2010). Jurnal Kesehatan Resproduksi, 1(3), 145-154.

UPTD Puskesmas Harapan Raya Pekanbaru. (2018). DATA HIV DAN IMS REMAJA UPTD PKM HR PKU 2017.

Yulianingsih, E. (2015). Faktor-faktor yang berhubungan dengan tindakan berisiko tertular hiv/aids pada siswa SMA negeri di kota Gorontalo. JIMU, 5(2a), 311-321. 